\title{
Vocational Teachers' Perceptions and Perspectives in the Implementation of STEM Learning in the 21st Century
}

\author{
Muhammad Nurtanto ${ }^{1}$, Putu Sudira ${ }^{2}$, Nur Kholifah ${ }^{3}$, \\ Achmad Samsudin ${ }^{4}$, Warju Warju ${ }^{5}$ \\ ${ }^{1}$ Department of Mechanical Engineering Education, Universitas Sultan Ageng Tirtayasa, Jl. Raya Jakarta Km \\ 4, Banten, Indonesia \\ ${ }^{2}$ Technical and Vocational Education, Graduate School, Yogyakarta State University Jl. Colombo No.1, \\ Yogyakarta, Indonesia \\ ${ }^{3}$ Department of Culinary and Fashion Education, Yogyakarta State University, \\ Jl. Colombo No.1, Yogyakarta, Indonesia \\ ${ }^{4}$ Department of Physics Education, Universitas Pendidikan Indonesia, Jl. Dr. Setiabudi No.229, Isola, \\ Kec. Sukasari, Kota Bandung, Jawa Barat 40154, Indonesia \\ ${ }^{5}$ Department of Mechanical Engineering, Faculty of Engineering, Universitas Negeri Surabaya, Jl. Ketintang, \\ Surabaya, 60213, Indonesia
}

\begin{abstract}
The purpose of this study is to measure perceptions and analyse the perspectives of vocational teachers related to STEM understanding. A total of 157 respondents were actively involved in providing perceptual assessments with a score of 1-5 (rating scale). A total of $\mathbf{1 0}$ participants were involved in indepth interviews to see the vocational perspective. The results of the study showed that the perception of vocational teachers obtained a score of $77.5 \%(\mathrm{M}=$ 3.87, $\mathrm{SD}=.63)$. The descriptive analysis explains that the implementation of learning considers the preparation, implementation, carrying capacity of leaders, in order to produce skills appropriately. The aspect of collaboration skills is a key factor in the success of STEM learning, considering multidisciplinary.
\end{abstract}

Keywords - STEM education, teacher perception, vocational teacher, learning reform

DOI: 10.18421/TEM94-46

https://doi.org/10.18421/TEM94-46

Corresponding author: Muhammad Nurtanto,

Universitas Sultan Ageng Tirtayasa-Jl. Raya Jakarta Km 4, Banten, Indonesia.

Email: mnurtanto23@untirta.ac.id

Received: 13 July 2020.

Revised: 11 October 2020.

Accepted: 16 October 2020.

Published: 27 November 2020.

(cc) BY-NC-ND (C) 2020 Muhammad Nurtanto at al; published by UIKTEN. This work is licensed under the Creative Commons Attribution-NonCommercial-NoDerivs 4.0 License.

The article is published with Open Access at www.temjournal.com

\section{Introduction}

The 21st century has been underway, along with challenges in the Industrial Revolution 4.0 era that had an influence on education, including vocational education in Indonesia. However, future learning involves the role of technology as much as the development of the industry today [1] has involved, and various fields of work are carried out in a mechanical manner. Even so, technology in the industrial world has been divided into three categories [2], namely high technology, partially technological, and technology no role at all. High role technology has been carried out in stages by reducing the human labor in various fields. Technology will not play a role in the lower middle industry (Medium Enterprise Community Activities) or jobs at the local level. However, the technology involved is very expensive despite increased productivity. Seeing the development of this technology, vocational education graduates have to have a similar experience. So, technology plays a role in the implementation of learning [3], and the achievement of practical competencies as a form of environmental adaptation.

Until now, learning in vocational education still stands alone [4]. Whereas, the curriculum in vocational education has the same goal, namely, to produce individuals with work skills and independence. In addition, each job or work competency involves disciplines from various fields. This implies, in accordance with the challenges of globalization, that students have to have multi skills [5], [6]. Thus, engagement between subjects and engagement between teachers is important to discuss. 
This concept is referred as multidisciplinary science or trans-disciplinary or meta-discipline [7]. Developed countries have developed this concept for a long time and have a real impact on the economy and the level of independence of the country. This learning concept is called STEM learning, namely science-technology-engineering-mathematics). Each learning objective is associated with these disciplines, so learning is more meaningful [8]. Vocational education has the suitability of space in the application of STEM where technology and engineering are strong elements and are more dominant in future work.

STEM learning is a new pattern applied in Indonesia. The STEM concept was developed through the Professional Development Program in vocational teacher advice through training and mentoring for three years. This program has been implemented since 2019, involving 34 vocational schools in various regions in Indonesia as STEM reference schools. The presence of STEM is believed to be able to provide a change in the quality of learning in vocational education. An important point of STEM learning is to equip students to have creative, analytical, and critical skills and life skills. To realize this goal, vocational teachers are an element of success in STEM learning [9].

Vocational teachers have to understand the role and application of STEM, especially in solving problems in the surrounding environment with various cases experienced by students in daily life. This will be easily understood and remembered by students. Learning by involving experiences or events that have been experienced by students makes it easy to store information into memory and re-call back, if needed. One example, an incident in the neighborhood is a case of motorcycle theft. Such cases can be resolved by involving various multidisciplinary sciences. It can be seen from the Science side, which is - What material will be used? From the mathematical side is - How is the output of the circuit? From the engineering side is -What an effective vehicle safety circuit is? From the technology side - Which concept is to be applied? Previous researchers have described STEM objectives more on the exploration, discovery and problem solving [7]. So, one of the cases above can be resolved using the STEM approach by bringing problems into the classroom to be analyzed together. However, the teacher as a facilitator among students as objects in solving these problems.

However, the current weakness is that all basic competencies in the curriculum cannot be oriented and resolved through STEM learning. Assist verbs with cognitive levels of analysis, evaluation, and creation are needed to implement STEM. The STEM implementation has several types including silos, embedded, and integrated. Types of silos can be done by vocational teachers on selected competencies, but considering the elements contained in STEM. The embedded type is a project with competencies appearing in various subjects, so together they determine the competency limits to achieve this goal. The integrated type in which between different subjects or grade levels there is the same project with completed alternations in accordance with the level of difficulty and ability possessed. Implementation of STEM learning is not easy. It requires continuous learning experience.

The purpose of this study is to measure perceptions based on knowledge, behavior, emotion, and motivation of vocational teachers and describe the experience of vocational teachers in implementing STEM learning. The benefits of conducting research are being input for the organizers of vocational learning in order to improve perceptions and analyze appropriate strategies of competencies, so that learning is more effective, meets work standards and by which students can face global challenges.

\section{Research Methods}

Quantitative and qualitative research were adopted. Researchers use a survey approach that aims at seeing open responses and questionnaires from vocational teachers based on their experience in implementing the STEM program. The implementation of the STEM program which is carried out in the middle of the semester results in less conducive program planning, so in-depth information is needed through the experience of vocational teachers [10]. Survey research is carried out by collecting data with a certain time limit, through questions according to the nature of the conditions that exist in the field. A total of 5 vocational schools, including three public schools and two private schools, in Yogyakarta with the participation of 157 vocational teachers were involved in filling out the questionnaire with a closed statement. Closed statement aims to measure the perception of vocational teachers based on events experienced directly. Respondent data in detail are shown in Table 1.

\section{Table 1. Respondent Data}

\begin{tabular}{llcc}
\hline Respondent Criteria & $:$ & F & \% \\
\hline School status & & & \\
$\quad$ Public school & $:$ & 105 & 66.88 \\
$\quad$ Private school & $:$ & 52 & 33.12 \\
\hline Gender & & & \\
$\quad$ Male Teacher & $:$ & 97 & 61.8 \\
Female Teacher & $:$ & 60 & 38.2 \\
\hline Ages & & & \\
21-30 years & $:$ & 37 & 23.57 \\
31-40 years & $:$ & 65 & 41.40 \\
41-50 years & $:$ & 12 & 7.64 \\
$\geq 51$ years & $:$ & 43 & 27.39 \\
\hline
\end{tabular}


The developed instrument considers the validation of experts from VEDC BOE Malang as an instructor during the STEM program. The STEM learning program carried out is a new method for vocational teachers and has the learning characteristics needed in the 21st century, so some questionable items are linked to 21 st century skills. Closed questions to measure perceptions of vocational teachers include knowledge of vocational teachers, behavior of vocational teachers, emotion of vocational teachers, and motivation of vocational teachers. Measurements were made using a rating scale with a score of 1-5.

The instrument with an open statement was developed through 7 items of research questions. The questions revealed the experience of vocational teachers during the implementation of the STEM program. The research questions are as follows:

\begin{tabular}{|c|c|}
\hline RQ1 & $\begin{array}{l}\text { What do you know about STEM } \\
\text { education? }\end{array}$ \\
\hline RQ2 & $\begin{array}{l}\text { What do you know about the need for } \\
\text { skills in the } 21 \text { st Century? }\end{array}$ \\
\hline RQ3 & $\begin{array}{l}\text { Is STEM Education able to improve } \\
\text { skills in the } 21 \text { st Century? What are } \\
\text { your considerations? }\end{array}$ \\
\hline RQ4 & $\begin{array}{l}\text { Does the school support the learning } \\
\text { process using STEM education? }\end{array}$ \\
\hline RQ5 & $\begin{array}{l}\text { How do you determine the learning } \\
\text { objectives using STEM education? }\end{array}$ \\
\hline RQ6 & $\begin{array}{l}\text { Did you experience any difficulties } \\
\text { while implementing STEM? What } \\
\text { difficulties are you experiencing? }\end{array}$ \\
\hline RQ7 & $\begin{array}{l}\text { What methods do you use to support } \\
\text { successful learning using STEM? }\end{array}$ \\
\hline
\end{tabular}

Each school is represented by two vocational teachers in each project in different groups. Two teachers who fill open questions are teachers who convey their experiences after they have finished displaying learning outcomes. They conveyed the experience of applying STEM learning in theory and practice. Researchers assume that selected vocational teachers are considered capable and successful in implementing STEM learning, so interviews and brief notes are addressed to them.

The results of the responses from vocational teachers were analyzed using interpretation methods to be interpreted and grouped based on the characteristics of their understanding and experience. Every aspect of the open-ended question is coded according to the researchers' point of view which is confirmed by the participants to make perceptions (confirmatory). In addition, statistical methods are used to interpret data from closed statements because of the perception of vocational teachers, leading towards the implementation of STEM learning.

\section{Result and Discussion}

\subsection{Perception of Vocational Teacher}

The results of the implementation of the STEM learning professional development program for vocational teachers in Yogyakarta are based on the four identified variables presented in Table 2.

Table 2. Perceptions of Vocational Teachers in STEM Learning Programs

\begin{tabular}{|c|c|c|c|}
\hline Questionable Item (QI1-QI7) & $\mathbf{N}$ & Mean & Std. Deviation \\
\hline $\begin{array}{l}\text { 1) I can master how STEM learning can be implemented into } \\
\text { vocational learning }\end{array}$ & 157 & 3.78 & .70 \\
\hline I can develop learning STEM based on core competencies & 157 & 3.69 & .64 \\
\hline I feel satisfied implementing learning using STEM & 157 & 3.96 & .67 \\
\hline I feel anxious, if learning using STEM will not work & 157 & 3.85 & .76 \\
\hline $\begin{array}{l}\text { 5) I can choose a STEM-based learning approach based on the } \\
\text { competencies I teach }\end{array}$ & 157 & 3.80 & .68 \\
\hline $\begin{array}{l}\text { 6) I can arrange the STEM-based learning stages that produce } \\
\text { active learning }\end{array}$ & 157 & 4.00 & .54 \\
\hline $\begin{array}{l}\text { 7) I can condition the atmosphere of learning and produce } \\
\text { meaningful learning }\end{array}$ & 157 & 4.06 & .44 \\
\hline $\begin{array}{l}\text { 8) I am willing to use STEM in the next study and for learning the } \\
\text { long term }\end{array}$ & 157 & 3.88 & .47 \\
\hline 9) I can prepare STEM learning on other competencies & 157 & 3.83 & .80 \\
\hline \multicolumn{2}{|c|}{ Overall mean } & 3.87 & .63 \\
\hline
\end{tabular}

The results of the vocational teachers' knowledge variable on STEM learning [QI1 and QI2] obtained an average of $74.7 \%(\mathrm{M}=3.74, \mathrm{SD}=.67)$. The results of the variable behavior of vocational teachers towards learning STEM [QI3 and QI4] obtained an average of $78.2 \%(\mathrm{M}=3.91, \mathrm{SD}=.72)$. The results of the emotion variables of vocational teachers in implementing STEM were $79.1 \%(\mathrm{M}=3.95, \mathrm{SD}=$ .56). The results, the variable motivation of vocational teachers during the implementation of STEM obtained an average of $77.1 \%(\mathrm{M}=3.86$, SD $=.64)$. Overall, of the four variables determined, the perception of 
vocational teachers in the implementation of STEM learning was $77.5 \%(\mathrm{M}=3.87, \mathrm{SD}=.63)$.

Overall vocational teacher perceptions are of "good" decisions. That is, vocational teachers during implementing STEM-based learning in a knowledge of STEM, behavior during the implementation of STEM-based learning, vocational teacher emotions in STEM-based implementation, and motivation of vocational teachers as a whole is good $(77.1 \%$ $79.1 \%$ ). Although, in the implementation of learning found many diverse perspectives. However, the results of teachers' perceptions describe that vocational teachers agree with STEM, learning the quality of learning has increased.

The lowest acquisition of vocational teachers on the element of knowledge (QI2) is about the ability of teachers to develop STEM-based learning. The researcher observed directly during the mentoring process in the STEM program, that overall the difficulties experienced by vocational teachers are the same, namely the perspective of the curriculum in distributing basic competencies are to be conceptualized into STEM-based learning [11]. They understand that STEM is a product and multidisciplinary science, so the three use verbs such as mentioned and explained, makes it difficult to carry on the STEM concept. Of course, vocational teachers recommend that through MGMP (teacher's organization) or learning, planning in vocational schools, basic competencies can be developed more deeply.

The highest acquisition of vocational teachers' perceptions on the emotional element of the teacher (QI7) is related to the teacher's ability to condition the classroom. However, referral schools have adopted various previous scientific methods such as PBL, EDP, and others. So that during the learning process the STEM concept combined with the method did not experience significant changes. This is because the STEM is more strengthened than the elements of each discipline that strengthen competence in learning [12]. Thus, the method as a stage of the learning process is not difficult for teachers.

\subsection{The perspective of STEM learning of 21st Century skills}

\subsubsection{Vocational Teacher Understanding (RQ1)}

Vocational teachers in Vocational Schools in Yogyakarta understand STEM learning in two categories, namely product and multidisciplinary science. Their explanation regarding STEM is as follows:

"My understanding of STEM is more about the product. Yes, EDP (Engineering Design Product), so indeed how the teacher, raises student understanding, student understanding, because now the basis of competence is the same character, we cannot equate abilities with each other, but how students can understand a problem.", [G1]

"The beginning of STEM stands for STEM is Science, Engineering, Technology, and Mathematics. We know that STEM is a combination of several subjects or multidisciplinary sciences" [G2]

The teacher's understanding as basic thinking is appropriate, where STEM learning aims to produce a product by involving other disciplines in certain competencies [13]. The intended product has a broad meaning that is something produced by students in real terms, such as procedures, instructions, design, project, problem solving, and so on. However, to strengthen the concept to students, STEM learning will be meaningful when solving problems that exist in the surrounding environment [14], and it is better often experienced by students.

During the implementation of STEM learning, the teacher only conditions and ensures that students feel comfortable in learning (facilitator function) [15]. Vocational teachers may not be deeply involved in the projects that have been provided. Some recommendations for vocational education, products that are packaged in learning, are more meaningful when applying the EDP method for the reason that, in the process the stages involve elements of engineering and technology predominantly.

\subsubsection{STEM and 21st Century Skills (RQ2 and RQ3)}

Vocational teachers interpret 21 st century skills into four elements, namely student-centered learning, collaboration, problem solving in daily life, and responsibility. The direct expression of the vocational teacher is as follows:

\footnotetext{
"We understand that in the 21 st century skills, at least the learning changes that the teacher initially explained explain must shift that students participate in learning. In addition, a team was formed to be able to complete the tasks given in groups. ... In the industry, they must be able to work in teams." [G7]

"21st century skills where students are given problems of life in the surrounding environment. So that their memories procedurally and concepts can be applied to similar problems. No less important, the main thing is the attitude of responsibility." [G4]
}

Vocational teachers explain the involvement of STEM learning support for the achievement of $21 \mathrm{st}$ century skills, as follows:

"STEM has very good potential, if done in full. During this time, the learning process of teachers is individual. Through STEM between teachers, between competencies, between class levels, even between disciplines can complete a learning with each scientific 
approach. If the teacher realizes that one competency is not strong enough to stand alone, then ScienceTechnology-Engineering, and Mathematics is the right solution for future learning. This is where the actual skills, teachers and students engage in STEM-based learning as a form of practice long-term manifestation skills." [G8]

Halim revealed that STEM education is an effective way of applying skills in the 21st century [16]. Developed countries have implemented the STEM education concept earlier and have made changes in their economic progress and career paths. With STEM learning skills in problem solving, critical and analytical thinking can be developed [17]. In line with global challenges, that future skill is the mastery of competencies through multidisciplinary science [18], none other than implementing STEM based learning.

\subsubsection{Carrying Capacity (RQ4)}

Learning success is inseparable from the support of the leadership authority and the availability of infrastructure. If these elements are not met, then vocational learning will be deadlocked. The STEM education program is carried out in the middle of the current semester. The vocational teacher's statement of school support is as follows:

"During the guidance it was very supportive, only from the beginning I have said, because this program is in the midst of learning from the government, the schools have not budgeted there, so the support is constrained for funding. " [G6]

School leaders support government programs, but since the program is implemented in the middle of the semester, the school is not ready for the budget. This happens in public vocational schools, because budget absorption is done at the beginning of learning [19]. In contrast to private vocational schools, although the absorption of the budget at the beginning of a semester, budget changes can be made in the middle of the program. So, the difficulty in implementing STEM learning is material support in the form of budget. They (the teachers) have difficulty when planning projects with large budget needs [20]. Finally, the project did not solve important and urgent problems. However, the next STEM learning has to be better planned.

\subsubsection{Implementation Difficulties (RQ5, RQ6 and RQ7)}

STEM learning that is new to vocational school levels unknowingly found several difficulties in the implementation. Many approaches to STEM implementation include silos, embedded, and integrated [21]. From the various approaches, the difficulties faced are almost the same, namely the planning and implementation stages, while the evaluation stage is not problematic.
"The difficulty we experienced (the teachers) was to sort out which competencies were potential for STEM learning. Not all verbs (KKO) support for STEM. Our hope for the next implementation of the teachers through MGMP or learning preparatory meeting, the school has a program or project planning for STEM." [G5]
"Conditioning the number of students more than 30 people is very difficult. Especially when it gets a direct evaluation from Widyaiswara (VEDC BOE Malang). Promoting the elements of Science - Technology - Engineering -Mathematics is not easy. We, when playing a role, namely STEM learning in theory, in class, about machining, namely lathe, received input that science and mathematics were not yet detailed and in-depth. Other vocational teachers must also experience the same difficulties in playing the role of other disciplines. But STEM must still be implemented." [G10]
"The method used by the teacher is very varied, but the grouping consists of PBL, PjBL, and EDP. So far, the presentation on exposures considered complete is EDP. " [G9]

The implementation of vocational learning using the STEM concept considers: (1) basic competencies that have the potential for learning STEM, not all competencies can be designed to conduct STEM learning. In the selection of competencies, the vocational teacher has to see the four elements involved in learning planning. At least three important elements, namely content with a technology, engineering, and one of science match points of this view. For vocational teachers who are beginners it is not easy to analyze basic competencies. A joint program is needed in the MGMP or preparation for the semester. The goal is vocational teacher involvement and budget for completing the project; (2) STEM learning strategies (silo, embedded or integrated) between disciplinary teachers or between subjects in a project with the same competency content; (3) the selection of methods that fit the characteristics of basic competencies (EDP, PjBL, PBL, and others). However, it is important to consider the support of schools in terms of implementation authority and budget support.

\section{Conclusion}

This study describes STEM learning as meaningful learning. STEM learning in vocational education can produce quality students, according to 21 st century skills. The STEM learning program implemented obtained the following results: (1) overall vocational teacher perceptions of $77.5 \%(\mathrm{M}=3.87, \mathrm{SD}=.63)$ in 
good decisions; and (2) the teacher's perspective based on his understanding that STEM is interpreted as project-based learning involving other disciplines. There are four elements of STEM involvement within 21 st century skills, and they are student centered, collaboration, problem solving and responsibility, the need for carrying capacity of STEM is support from vocational school leaders in the form of morale and material. Difficulties during implementation include the distribution of curriculum into STEM learning, implementation strategies, and appropriate methods.

\section{References}

[1]. Nagy, J., Oláh, J., Erdei, E., Máté, D., \& Popp, J. (2018). The role and impact of Industry 4.0 and the internet of things on the business strategy of the value chain - the case of Hungary. Sustainability, 10(10), 3491. https://doi.org/10.3390/su10103491

[2]. Li, B., \& Piachaud, D. (2019). Technological innovations and social development in Asia. Journal of Asian Public Policy, 12(1), 1-14. https://doi.org/10.1080/17516234.2018.1546419

[3]. D'Agustino, S. (Ed.). (2010). Adaptation, Resistance and Access to Instructional Technologies: Assessing Future Trends In Education: Assessing Future Trends In Education. IGI Global.

[4]. Billett, S. (2000). Defining the demand side of vocational education and training: industry, enterprises, individuals and regions. Journal of vocational education and training, 52(1), 5-31. https://doi.org/10.1080/13636820000200104

[5]. Durib, M. J. (2014). Challenges of globalization to school curricula from the point of view of faculty members with suggestions of how to deal with it. Procedia-Social and Behavioral Sciences, 112, 1196-1206. https://doi.org/10.1016/j.sbspro.2014.01.1284

[6]. Rasmitadila, R., Rachmadtullah, R., Samsudin, A., Tambunan, A., Khairas, E., \& Nurtanto, M. (2020). The Benefits of Implementation of an Instructional Strategy Model Based on the Brain's Natural Learning Systems in Inclusive Classrooms in Higher Education. International Journal of Emerging Technologies in Learning (iJET), 15(18), 53-72.

[7]. Ceylan, S., \& Ozdilek, Z. (2015). Improving a sample lesson plan for secondary science courses within the STEM education. Procedia-Social and Behavioral Sciences, 177, 223-228. https://doi.org/10.1016/j.sbspro.2015.02.395

[8]. Figliano, F. J. (2007). Strategies for integrating STEM content: A pilot case study (Doctoral dissertation, Virginia Tech).
[9]. Rinke, C. R., Gladstone-Brown, W., Kinlaw, C. R., \& Cappiello, J. (2016). Characterizing STEM teacher education: Affordances and constraints of explicit STEM preparation for elementary teachers. School Science and Mathematics, 116(6), 300-309. https://doi.org/10.1111/ssm.12185

[10]. Cohen, L., Manion, L., \& Morrison, K. (2007). Strategies for data collection and researching: Questionnaire. Research methods in education. 6th edition. Routledge, Abingdon, United Kingdom, 31746.

[11]. Kelley, T. R., \& Knowles, J. G. (2016). A conceptual framework for integrated STEM education. International Journal of STEM Education, 3(1), 11. https://doi.org/10.1186/s40594-016-0046-z

[12]. Thi To Khuyen, N. G. U. Y. E. N., Van Bien, N. G. U. Y. E. N., Lin, P. L., Lin, J., \& Chang, C. Y. (2020). Measuring Teachers' Perceptions to Sustain STEM Education Development. Sustainability, 12(4), 1531. https://doi.org/10.3390/su12041531

[13]. Hsu, Y. S., \& Yeh, Y. F. (Eds.). (2019). Asia-Pacific STEM Teaching Practices: From Theoretical Frameworks to Practices. Springer Nature.

[14]. Sahin, A., \& Mohr-Schroeder, M. J. (Eds.). (2019). STEM Education 2.0: Myths and Truths-What Has K-12 STEM Education Research Taught Us?. BRILL.

[15]. Bucholz, J. L., \& Sheffler, J. L. (2009). Creating a warm and inclusive classroom environment: Planning for all children to feel welcome. Electronic Journal for Inclusive Education, 2(4), 1-13.

[16]. Halim, L. (2013). Pendidikan sains dan pembangunan masyarakat berliterasi sains. Penerbit Universiti Kebangsaan Malaysia.

[17]. Brown, A. E., Christensen, H., Gonon, P., Hogarth, T., \& Luomi, K. (2017). Conceptions of Vocational Education and Training - An analytical framework 1.

[18]. Becker, K., \& Park, K. (2011). Effects of integrative approaches among science, technology, engineering, and mathematics (STEM) subjects on students' learning: A preliminary meta-analysis. Journal of STEM Education: Innovations \& Research, 12.

[19]. Friyani, R., \& Hernando, R. (2019). Determinants of The Effectiveness Of Implementation Performance Based-Budgeting and Budget Absorption in Local Government (Study on Jambi City Government). Sriwijaya International Journal Of Dynamic Economics And Business, 3(3), 213-226. https://doi.org/10.29259/sijdeb.v3i3.213-226

[20]. Kang, N. H. (2019). A review of the effect of integrated STEM or STEAM (science, technology, engineering, arts, and mathematics) education in South Korea. Asia-Pacific Science Education, 5(1), 122. https://doi.org/10.1186/s41029-019-0034-y

[21]. Roberts, A., \& Cantu, D. (2012). Applying STEM Instructional Strategies to Design and Technology Curriculum. Technology Education in the 21st Century, 111. 